\title{
Comparative Study of New and Old Regulations of Students Management in Colleges
}

\author{
Xingping Lan, Tao Yang, Guoqin Chen \\ Yunnan Jiaotong College, Kunming, Yunnan, 650500
}

Keywords: colleges; management regulations; comparison

\begin{abstract}
The "Provisions on the Management of Students in Colleges" promulgated by the Ministry of Education in 2017 have a series of new ideas and measures for the education proposed by the Party Central Committee since the 18th CPC National Congress to the practice of student management in Colleges. In order to conscientiously implement this regulation, this paper, by means of comparative analysis, sorts out the parts of this regulation that are different from the old ones in theory, in order to enhance the ability of students in higher vocational colleges to manage their services in a targeted manner in future practice.
\end{abstract}

\section{Introduction}

With the overall deepening of reform, the development of vocational education has become one of the strategic measures to promote the transformation of the economy, structural adjustment and improvement of people's livelihood. The Third Plenary Session of the 18th CPC Central Committee pointed out the direction for the reform of vocational education - "speeding up the construction of a modern vocational education system, deepening the integration of production and teaching, strengthening the cooperation between schools and enterprises, and cultivating high-quality laborers and skilled personnel." On the one hand, as of 2015, the number of independent higher vocational colleges nationwide reached 1,341, with 10.48 million students enrolled, accounting for $41.2 \%$ of higher education. As the "half of the country" in higher education, higher vocational education is developing rapidly; In respect of the newly promulgated Provisions on Student Management of Colleges in 2017 by the Ministry of Education, the 18th CPC National Congress, the 3rd, 4th, 5th, 6th Plenary Sessions of the 18th CPC Central Committee and the National Conference on Ideological and Political Work in Colleges put forward some relevant proposals The new ideas, new ideas and new measures in education are implemented in the management of students in Colleges. This requires that the management team of students in higher vocational colleges must keep pace with the times and earnestly implement the new requirements so as to create a safe campus and a harmonious campus Improve management and service level, and strive to cultivate high-quality laborers and skilled personnel.

Comparing the Regulations on the Management of College Students promulgated in 2017 (hereinafter referred to as the "New Regulations") and the Regulations on the Management of Colleges Students (hereinafter referred to as the "Old Regulations") promulgated in 2005, Students ideological and moral evaluation of the main basis for identifying and safeguarding the rights and interests of students, according to the law and student innovation and entrepreneurship are different.

\section{The purpose of enacting the new regulations}

In the first chapter of the "General Provisions" in the first article, the new provisions than the old provisions increased "to standardize the general

Through the management of college students behavior "and the old rules" to protect the physical and mental health "upgrade to" protect the legitimate rights and interests of students. " 


\section{University tasks}

In order to train socialist builders and successors, the old stipulation states in Article 3 of Chapter 1 that "the center is to cultivate qualified personnel." The new stipulation is also proposed in Article 3 of Chapter 1 that "we should take Lideshu people as the foundation and take the ideal Faith education as the core, cultivating and practicing the core values of socialism, carrying forward the outstanding Chinese traditional culture and revolutionary culture, the advanced culture of socialism, and cultivating students' sense of social responsibility, innovative spirit and practical ability. " The old rules put forward "strict management" and "continuously improve the management level". The new regulation proposed "scientific management" and "continuously improve the management and service level."

\section{The main basis for the assessment of students' ideological and moral character}

The main basis for the old rules is the "Code of Conduct for College Students"; the main new provisions

According to Article 4 of Chapter 1, it is clearly stated that "students should support the leadership of the Communist Party of China and work hard to study the theoretical system of Marxism-Leninism, Mao Zedong Thought and socialism with Chinese characteristics, further study the important speech made by General Secretary Xi Jinping and the new administration of state affairs We must establish a new ideology, a new ideology and a new strategy, strengthen the road of socialism with Chinese characteristics: self-confidence, theoretical self-confidence, institutional self-confidence, cultural self-confidence and the common ideal of building socialism with Chinese characteristics. We should establish a patriotic ideology and be united and reunified, peace-loving, industrious and courageous, ; Should strengthen the concept of the rule of law, abide by the constitution, laws and regulations, abide by the civic code of ethics, abide by the school management system, with good moral character and behavior; should study hard, explore courageously, practice actively, and strive to master modern science and culture knowledge and professional Skills; should be actively exercise, improve physical and mental health, improve personal accomplishment, develop aesthetic taste.

\section{To protect the rights and interests of students}

The new rules are added in Chapter I of the "General Provisions" Article 5: The implementation of student management shall respect and protect the legitimate rights of students, educate and guide students to assume their due obligations and responsibilities, encourage and support students to exercise self-management, self-service, Self-education, self-supervision.

The new regulation added "guidance and service for employment and entrepreneurship" in the second point of Chapter VI "student rights and obligations" and student rights, and at the same time added "science and technology innovation activities" in the scope of activities. The fourth point In addition to being "just", students' evaluation at school also calls for a "scientific" evaluation. On the seventh point, "other rights prescribed in the school charter" are added, highlighting the important status of the school's constitution.

The new regulations add content in Article 12 of "Student Status Management" section 1 "Admission and Registration" in Chapter 3, "Schools should provide education and assistance to students with financial difficulties based on the relevant state regulations to improve student financial support system so as to ensure students' Family economy to give up their studies. "

The new rules in Chapter 3, section IV, "suspension and resumption of school", an increase of Article 26: "schools can establish and implement a flexible learning system according to the circumstances. For students who start school and start their own business, may be the longest limit of their study, and Simplify the suspension of school approval process. "For the enrollment of college students, the school should retain their admission or enrollment to retirement after 2 years, while the old provisions of the retention period of only one year; added to the new added:" Students 
to participate in school organizations Cross-school co-cultivation project, in the joint school training school, the school at the same time to retain their student status ";" students to retain the student period, and its actual troops, schools and other organizations to establish management relations. "' National and local regulations to deal with. "

The new rules are added in Chapter V, "Rewarding and Disposal". Article 50: "Schools shall recognize and reward students, as well as determine the recommendations for exemption of postgraduates, state scholarships, public selections of returned overseas students, etc. to give the interests of students publicity should be established, Fair and equitable procedures and rules, and establish and improve the system of selection, publicity, etc. "Article 56 to increase the content" to cancel the admission of students qualifications, abolition of school, withdrawal, expulsion of school or other major interests involving students Handling or disposing of the case, it shall be submitted to the special meeting of the president's office or the president for study and decision, and a priori legal review shall be carried out. "In addition, Article 57 of the deadline for setting penalties is added:" In addition to expelling the student, Students should be punished in general should be set 6 to 12 months deadline, according to the school set out the procedure to be lifted. After dismissal, students receive recognition, rewards and other rights and interests, no longer subject to the original disciplinary action. "Yunnan Vocational and Technical College of Transportation for example, the school's newly revised "Student Handbook" clearly defined The deadline set for warnings is six months. The deadline for serious warnings is eight months. The deadline for recording the punishment is ten months and the deadline for leaving school for disciplinary action is twelve months.

The new rules are added in the second section of Chapter III, Article 20: "Schools should carry out honest education of students, and record the credit information of students in academic, academic and moral activities in an appropriate way so as to establish a restraining and punishing mechanism for dishonest behavior: If there is a serious dishonest act, a disciplinary measure may be made to provide appropriate disciplinary sanction. Anyone who violates academic integrity may be restricted in obtaining academic degrees, academic titles and honors.

The new regulations refer to Chapter 3, Section 3, "Transferring Majoring and Transferring," adding new requirements for transferring majors "Schools should formulate specific measures for students to transfer majors, establish fair and impartial standards and procedures, and improve the public announcement system" and stipulate that " Students who drop out of school or retired from school after graduation need to transfer their majors due to their own circumstances, and schools should give priority to them. "For the transfer, there are two additional cases that may not be transferred:" No transfer before the year of graduation "and" Schools, professional admission control standards higher than their school, professional. " The transfer of the program to increase the specific provisions: "transferred to the school is responsible for reviewing the transfer conditions and related certificates, that meet the training requirements of the school and the school has the ability to train, by the school principal conference or conference study decision, you can transfer. Should also be transferred to the professional mentor agreed. "

The new regulation, in Chapter 4, "Campus Order and Extracurricular Activities," maintains the normal order in schools. In addition to stipulating "schools", its subject adds "students" and requires schools and students to jointly "ensure the school environment is safe and stable." This chapter adds requirements to students and student groups: "Establish awareness of security risk prevention and self-protection to protect their own legitimate rights and interests." "No false or harmful information may be fabricated or disseminated; no attacks on or invasion of other people's computers and mobile communication network systems are allowed." Student groups should "implement the registration and annual inspection system." "Student groups invite outside organizations, personnel to hold seminars and other activities to be approved by the school." This chapter adds to the requirements of the school: "If a school discovers that a student is guilty of unlawful act in school or if any serious mental illness may cause harm to others, it may adopt or assist the relevant department to take the necessary measures according to law." "Schools should adhere to the principle of separating education from religion. "Schools should establish and perfect the student 
council system, provide the necessary conditions for student associations, postgraduate societies and other activities to support their role in student management." "Encourage and support students to implement self-regulation through the formulation of conventions."

The new rules in Chapter V, "Reward and Discipline," add two items to the scope of student dismissal: "Selling test questions or answers to others for profit" or "writing dissertations, buying and selling dissertations." In the aspect of student punishment, the content of the decision on punishment was added: "The decision on punishment shall include the basic information of the student; the type, basis and time limit of the punishment;" the content of the punishment shall be added: "If the student refuses to sign the application, May be served by indictment; those who have left school may be served by mail; those who are hard-pressed to contact may be served on the school website, the news media and the like by notice.

\section{Innovation and entrepreneurship}

The new rules in Chapter III of "student status management" section II "examination and record of the results," the addition of "students can participate in school recognized open network courses"; also added Article XVII: "Students to participate in innovation Entrepreneurship, social practice and other activities, as well as publishing papers, obtaining patents and other professional learning and academic requirements-related experiences and achievements, can be converted into credits, included in academic performance, specific measures by the school. "' Schools should encourage, support and Instruct students to participate in social practice, innovation and entrepreneurship, you can create a record of innovation and entrepreneurship, set the credits for innovation and entrepreneurship.

Through the above comparative analysis, we can see that the new regulations have higher requirements for students' management and service work, more safeguard students' rights and interests, and at the same time have the rules and regulations in accordance with the law governed the school. The encouragement for students' innovation and entrepreneurship has also been institutionalized. Only by thoroughly comprehending the new regulations and combining the various rules and regulations of Colleges that have been revised and perfected can we truly serve the people, serve the students well and cultivate the socialist builders and successors!

\section{References}

[1] "General Colleges Students Management Regulations."

[2] "Regulations on the Management of Colleges Students" .2017.1.

[3] "Higher Vocational Education Innovation and Development Action Plan (2015-2018)". 2015.13.

[4] "Yunnan Traffic Polytechnic Student Handbook (School Rules and Regulations Festival Edition)." 2017-8.33. 